\title{
Results of the surgical treatment of patients suffering from bronchopulmonary carcinoid tumors in the Department of Thoracic Surgery in Bystra in the period 1990-2011
}

\author{
Alina J. Wiencek-Weiss ${ }^{1}$, Piotr Wandzel ${ }^{2}$, Paweł B. Rogoziński ${ }^{1}$, Tomasz Kaczor ${ }^{1}$, Józef Ryszka ${ }^{1}$, \\ Witold Brózda ${ }^{1}$, Adam Bubel ${ }^{1}$, Krzysztof Bruliński ${ }^{1}$ \\ ${ }^{1}$ Department of Thoracic Surgery, Pulmonology and Thoracic Surgery Center, Bystra \\ 2Department of Pathomorphology, Beskidy Oncology Center, Bielsko-Biała \\ Kardiochirurgia i Torakochirurgia Polska 2013; 10 (1): 34-41
}

\begin{abstract}
Background: The new classification and terminology concerning neuroendocrine tumors, according to the European Neuroendocrine Tumor Society (ENETS) guidelines, were not universally accepted for bronchopulmonary carcinoids. That is why the term "carcinoid" is still being used in its traditional meaning. Precise identification of bronchopulmonary carcinoid subtypes constitutes an important prognostic factor.

Aim of the study: The aim of the study was to present the results of bronchopulmonary carcinoid surgical treatment conducted at the Department of Thoracic Surgery in Bystra, to assess the surgery material in accordance with the WHO 1999 (Travis) classification, and to compare the clinical courses of typical and atypical carcinoid tumors.

Material and methods: The analysis included 159 patients aged 18-77, treated surgically due to bronchopulmonary carcinoids in the years 1990-2011. Reassessment of histological preparations was carried out according to the WHO 1999 (Travis) and International Association for the Study of Lung Cancer (IASLC) classification; check-ups of the treated patients were performed as well. Disease-free interval (DFI) and overall survival were assessed with the Kaplan-Meier method; the clinical course of typical and atypical carcinoids was compared.

Results: As a result of the histological reassessment, $142 \mathrm{pa}$ tients $(88.3 \%)$ were diagnosed with typical carcinoids, and 17 patients (11.7\%) with atypical carcinoids. During the followup period, local disease recurrence occurred in 8 (4.9\%) patients, distant metastases in $13(8.2 \%)$ patients. There were $26(16.4 \%)$ instances of death -2 because of other malignant neoplasms. The DFI median ( $p=0.00003)$ and overall survival $(p<0.00001)$ were significantly longer in patients with typical carcinoids than in patients with atypical types of the tumor. Conclusions: The histological subtype of a bronchopulmonary carcinoid tumor is the dominant prognostic factor in assessing the DFI and the 5-year survival after surgery.

Key words: typical carcinoid, atypical carcinoid, neuroendocrine tumors.
\end{abstract}

\section{Streszczenie}

Wstęp: Wprowadzona nowa klasyfikacja i terminologia guzów neuroendokrynnych zgodnie z wytycznymi European Neuroendocrine Tumor Society (ENETS) nie została powszechnie przyjęta w odniesieniu do rakowiaka oskrzelowo-płucnego i nadal używa się określenia „rakowiak” w tradycyjnym ujęciu. Dokładna identyfikacja podtypu rakowiaka oskrzelowo-płucnego ma istotne znaczenie dla rokowania.

Cel pracy: Przedstawienie wyników leczenia operacyjnego rakowiaka oskrzelowo-płucnego na Oddziale Chirurgii Klatki Piersiowej w Bystrej, ocena histologiczna materiału operacyjnego zgodnie z klasyfikacją WHO 1999 - Travisa, a także porównanie przebiegu klinicznego rakowiaka typowego i atypowego.

Materiat i metody: Analizie poddano 159 chorych w wieku 1877 lat operowanych z powodu rakowiaka oskrzelowo-płucnego w latach 1990-2011. Przeprowadzono ponowną ocenę preparatów histologicznych na podstawie materiału archiwalnego zgodnie z klasyfikacją WHO 1999 - Travis i IASCL oraz badania kontrolne leczonych pacjentów. Dokonano oceny DFI i całkowitego przeżycia metodą Kaplana-Meiera oraz porównano przebieg kliniczny rakowiaka typowego i atypowego.

Wyniki: W wyniku ponownej weryfikacji histologicznej u 142 chorych (88,3\%) rozpoznano rakowiaka typowego, a u 17 chorych $(11,7 \%)$ atypowego. W okresie obserwacji nawrót miejscowy choroby wystąpił u $8(4,9 \%)$ chorych, a przerzuty odległe u $13(8,2 \%)$. Zmarło 26 (16,4\%) chorych, z czego dwóch z powodu innych nowotworów złośliwych. Mediana DFI $(p=0,00003)$ i całkowite przeżycie $(p<0,00001)$ było znamiennie dłuższe $u$ chorych z rakowiakiem typowym niż atypowym.

Wnioski: Podtyp histologiczny rakowiaka oskrzelowo-płucnego jest dominującym czynnikiem rokowniczym w ocenie DFI oraz 5-letniego przeżycia po leczeniu operacyjnym.

Słowa kluczowe: rakowiak typowy, rakowiak atypowy, guzy neuroendokrynne. 


\section{Introduction}

Bronchopulmonary carcinoid belongs to a heterogeneous group of neuroendocrine neoplasms. The identification of neuroendocrine features and the growth of knowledge concerning the origin and true nature of neuroendocrine cells of the respiratory system require an interdisciplinary approach to diagnosis and treatment.

The recent popularization of modern diagnostic methods increased interest in this fascinating and diverse group of neuroendocrine tumors and enhanced their detectability.

The term "carcinoid" (lat. carcinoidum), which means "similar to cancer", was introduced by Oberndorfer in 1907, when he was describing a group of intestinal tumors, the course of which was more benign than that of adenocarcinomas [1, 2].

However, the first description of a bronchial neoplasm which would suggest a carcinoid tumor based on the current knowledge was presumably made by Laennec as early as in 1831 [3].

Bronchopulmonary carcinoids constitute $1-5 \%$ of all primary lung cancer cases, $5-15 \%$ of all neuroendocrine tumors found in the human organism, and $19-24 \%$ of neuroendocrine lung tumors $[1,4]$. Currently, their incidence in the population is 1.57 cases per 100 thousand people a year.

The knowledge concerning the true nature of bronchopulmonary carcinoids is related to the development of research focused on the origin of the neuroendocrine cells of the respiratory system. It is currently believed that a neuroendocrine cell originates from an undifferentiated pluripotent stem cell, differentiating in the neurosecretory direction under the influence of local stimuli (inflammation and chronic oxygen deficiency) and participating in the growth and regeneration of respiratory epithelium and the process of carcinogenesis [5].

The proliferating neuroendocrine cells create small foci, forming nodules $5 \mathrm{~mm}$ in diameter, which remain in contact with bronchiolar epithelium and correspond morphologically to the notion of "tumorlet" ("tumor-like") introduced by Whitwell in 1955 [6]. Nodules larger than $5 \mathrm{~mm}$ in diameter are diagnosed as carcinoids.

The currently utilized morphological criteria, introduced by Arrigoni in 1972 and modified by Travis in 1998, enable the differentiation of carcinoids from other neuroendocrine tumors and the systematization of pulmonary neuroendocrine hyperplasias, emphasizing their differences from other lung tumors.

The generalized growth of neuroendocrine cells in the lungs, together with the clinical picture, provided the basis for the isolation of a separate nosological entity, described by Aguayo and included in the WHO classification in 1999 as DIPNECH (diffuse idiopathic pulmonary neuroendocrine cell hyperplasia), considered to be the preinvasive state of bronchopulmonary carcinoids $[4,7,8]$.

The newest WHO histopathological classification of neuroendocrine tumors from 2010 is based on clinical and pathological data, evaluated on the basis of anatomical, clinical, pathological, and functional characteristics of tumors and supplemented by immunohistochemical ex- amination [9]. It presents a uniform classification for all neuroendocrine tumors, with the criterion of their malignancy based on the following factors: tumor number, size and appearance, the depth of infiltration and the relation to the surrounding tissue, microscopic differentiation, angioinvasion, Ki-67 proliferation index (\%), mitotic index $\mathrm{MI}(\mathrm{X} / 10 \mathrm{HPF})$, and the presence of general immunohistochemical markers specifying the secretory profile of the tumor (in hormonally active tumors).

This classification concerns the gradation of gastroenteropancreatic neuroendocrine tumors (GEP NET), but some authors suggest using it also for neuroendocrine lung tumors. This classification distinguishes the following groups of tumors:

- G1 neuroendocrine tumor (NET G1): well-differentiated, high maturity, low malignancy - typical carcinoid (MI $<2 / 10 \mathrm{HPF}$, Ki- $67 \leq 2 \%)$;

- G2 neuroendocrine tumor (NET G2): well-differentiated, intermediate maturity, moderate malignancy - atypical carcinoid (MI 2-20/10 HPF, Ki-67 3-20\%);

- G3 neuroendocrine carcinoma (NEC): low maturity, high malignancy - large or small cell type (MI > 20/10 HPF, Ki-67 >20\%);

- mixed adenoneuroendocrine carcinoma (MANEC).

It is currently believed that the term "carcinoid" is a historical histopathological name defining neuroendocrine neoplasms since 1907, regardless of their location. It is recommended to use this term only for well-differentiated neuroendocrine tumors producing serotonin, with confirmed increase of its concentration in the blood or an increase of 5-hydroxyindoleacetic acid (5-HIAA) excretion in urine, and showing symptoms of carcinoid syndrome in the case of diffusion to the liver.

The new classification and terminology for neuroendocrine tumors introduced by the European Neuroendocrine Tumor Society (ENETS) is already widely used for gastroenteropancreatic neuroendocrine tumors (GEP NET) and is recommended by the Polish Network for Neuroendocrine Tumors. However, the changes in terminology have not been universally accepted with regard to bronchopulmonary carcinoids and the term "carcinoid" is still used in its earlier, traditional, and more general meaning, despite the fact that some pathomorphologists and oncologists utilize the new classification and nomenclature, which may lead to confusion and ambiguity.

\section{Aim of the study}

The aim of this study was to present the results of bronchopulmonary carcinoid surgical treatment conducted in the years 1990-2011 at the Thoracic Surgery Department in Bystra, the histopathological evaluation of the operative material (in accordance with the WHO classification of 1999 - Travis), and the comparison between the clinical courses of typical and atypical carcinoids.

\section{Material and methods}

The research included 159 patients aged 18-77 (52.6 on average), treated at the Thoracic Surgery Department in 
Bystra in the years 1990-2011 because of bronchopulmonary carcinoid tumors. There were 57 (35.8\%) men and $102(64.2 \%)$ women.

All the data related to disease symptoms, preoperative diagnostics, the course of operations, and postoperative evaluations were compiled on the basis of the archival documentation of the aforementioned institution.

The stage of bronchopulmonary carcinoids was established in accordance with the PTNM 1997 classification for lung cancer, based on the analysis of operative protocols and the results of histopathological examinations conducted by the IASLC.

The medical examinations were performed at the Thoracic Surgery Clinic in Bystra and additional information was acquired from the documentation of the Pulmonary Disease Clinics in the patients' home towns, as well as from letters and phone conversations with the patients and their families.

Information concerning the dates of deaths was acquired from the Department of Citizens' Affairs and Migration of the Śląskie Voivodeship Office in Katowice and the Department of Citizens' Affairs and Migration of the Małopolskie Voivodeship Office in Kraków.

The follow-up covered the period from the date of the surgery to the last check-up or death, and lasted between 2 and 262 months. Survival time was defined as the period between the date of the surgery and the last check-up or death, while disease-free interval was defined as the period between the surgery and the appearance of the first signs of local recurrence or distant metastases.

Histological examination of the postoperative material was conducted at the Institute of Pathomorphology of the Jagiellonian University Medical College in Kraków in the years 1990-2001 and the Department of Pathomorphology at the Beskid Oncology Center in Bielsko-Biała in the years 2002-2011.

Reevaluation of the histological preparations was conducted on the basis of archival material acquired from paraffin block samples taken from tumors during surgical procedures. The assessment of the tumors was performed in accordance with the WHO 1999 and IASLC classification, taking into consideration Travis' criteria for the differentiation of typical and atypical carcinoids.

Microscopic examination determined: the histological subtype of the tumor, size of the tumor $(\mathrm{cm})$, presence of necrosis, presence of angioinvasion, mitotic activity (X/10 HPF) and proliferation index $\mathrm{Ki}-67$ (\%).

Afterwards, the acquired results were analyzed statistically. The database was created using Excel XP for Windows, while the statistical analyses were conducted using Statistica v. 8.0 (StatSoft, Poland). When conducting the comparative analysis of quantitative variables, Student's t-test and the Mann-Whitney $U$ test were used depending on the normality of distribution and the homogeneity of variances. The correlation of qualitative data was performed by means of the chi-squared independence tests.

The Kaplan-Meier estimator was used in order to estimate the survival time and the disease-free interval
(DFI). The Gehan-Wilcoxon test was employed to compare the survival times and DFls estimated by means of the Kaplan-Meier method. Statistical inference error risk of $5 \%$ was assumed with a statistical significance level of $p<0.05$, pointing to the existence of statistically significant differences or correlations.

\section{Results}

Among the 159 patients operated on for bronchopulmonary carcinoids, 41 (25.8\%) were tobacco smokers and 118 (74.2\%) had never smoked cigarettes. In 63 (39.6\%) patients the disease course was clinically silent, while in 96 (60.4\%) patients different symptoms appeared in the period between 2 weeks and 6 years. In one patient, the carcinoid metastases to the liver preceded the lung tumor surgery by 8 years. Recurrent pneumonia was observed in 27 (28.1\%) patients, hemoptysis in $33(34.5 \%)$ patients, cough and increasing dyspnea in 34 (35.4\%) patients, carcinoid syndrome in 1 female patient (1\%) and Cushing's syndrome in one male patient (1\%). "Coin lesion" was observed in 54 out of the 63 patients who did not exhibit any ailments in the period between 2 months and 10 years. Due to the suspicion of a specific process, 8 patients received tuberculostatic treatment.

Bronchoscopic image was without deviation in 72 (45.3\%) patients, in $74(46.5 \%)$ patients the tumor was exophytic, growing toward the lumen of the bronchus, and in 13 (8.2\%) pts it had the form of a bronchial infiltrate. In 87 (54.7\%) cases the carcinoid tumor was located centrally and in 72 (45.3\%) cases peripherally.

Histopathological diagnosis was possible to establish before the operation in 82 (51.6\%) patients: in 75 pts on the basis of tumor samples acquired during bronchoscopy, in 5 pts on the basis of fine needle transthoracic biopsy, in 1 pt on the basis of the cytological examination of bronchial aspirate, and in 1 female patient during exploratory minithoracotomy. In 72 patients, the presence of a carcinoid tumor was confirmed, carcinoma planoepitheliale was diagnosed in 3 patients, carcinoma microcellularae in 2 patients, adenocarcinoma in 1 patient, carcinoma adenoidescysticum in 1 patient, and polipus in 3 patients.

The surgical treatment included lobectomy (bilobectomy) in 103 (64.8\%) patients (VATS in 3 patients), pneumonectomy in 4 (2.5\%) patients, wedge resection of the lung with a tumor or segmentectomy in 38 (23.9\%) patients, including 3 patients operated on by means of VATS, bronchotomy with wedge resection of the bronchus with a tumor in 11 (6.9\%) pts, and sleeve resection of the bronchus with a tumor in 3 patients (1.9\%).

As a result of the histopathological reassessment of the operative material, 9 tumors were reclassified in accordance with the WHO 1999 (Travis) criteria. In 4 cases, carcinoids previously diagnosed as typical were later classified as atypical, and in 5 cases atypical carcinoids were reclassified as typical. Finally, in 142 patients (88.3\%), typical carcinoids were diagnosed, while in 17 (11.7\%) patients atypical carcinoids were found. 
The following additional pathomorphological lesions were also revealed: arteriovenous fistula, sequestration, tuberculoma, foreign body, bronchiectasis, lung abscess, tumorlet type neuroendocrine nodules, DIPNECH, hyaline change and ossification, micronodular fibrosis, lung cyst, and minimal residual thymic tissue.

The diameters of the tumors were between $0.6 \mathrm{~cm}$ and $10 \mathrm{~cm}$. The average size was $2.06 \mathrm{~cm}$. Within the preand postoperative period, the patients underwent other operations and suffered from diseases other than bronchopulmonary carcinoid, including cancer, such as: gastric cancer - 1 , pancreatic cancer - 1 , adenocarcinoma of the other lung - 1, lymphoma - 1, hypernephroma - 1, adenocarcinoma of the uterus -3 , breast cancer -2 , meningioma of the brain -2 , glioma of the brain - 1 , follicular thyroid cancer - 1, and pituitary prolactinoma in 1 female patient.

In total, 8 patients received supplementary oncological treatment: 3 - radiation therapy, 3 - radiochemotherapy, and 2 - chemotherapy. Histological subtypes of bronchopulmonary carcinoids were compared with regard to clinical (Table I) and pathological (Table II) factors.

Tab. I. Histological subtypes of bronchopulmonary carcinoid tumor and clinical patient data (age, sex, tobacco smoking, and symptoms prior to surgery)

\begin{tabular}{|c|c|c|c|c|}
\hline \multicolumn{2}{|c|}{ Clinical factors } & $\begin{array}{l}\text { Typical } \\
\text { carcinoid }\end{array}$ & $\begin{array}{l}\text { Atypical } \\
\text { carcinoid }\end{array}$ & $\begin{array}{c}\text { Statistical } \\
\text { analysis }\end{array}$ \\
\hline \multirow{2}{*}{ age } & average & 52.19 & 56.35 & \multirow{2}{*}{$p=0.35$} \\
\hline & age range & $18-77$ & $39-67$ & \\
\hline \multirow{2}{*}{ sex } & M & $93(65.5 \%)$ & $9(52.9 \%)$ & \multirow{2}{*}{$\begin{array}{l}\chi_{c}=1.04 \\
p=0.31\end{array}$} \\
\hline & W & 49 (34.5\%) & $8(47.1 \%)$ & \\
\hline \multirow{2}{*}{$\begin{array}{l}\text { tobacco } \\
\text { smoking }\end{array}$} & no & 107 (75.4\%) & $11(64.7 \%)$ & \multirow{2}{*}{$\begin{array}{l}\chi_{c}=0.9 \\
p=0.34\end{array}$} \\
\hline & yes & 35 (24.6\%) & $6(35.3 \%)$ & \\
\hline \multirow{2}{*}{ symptoms } & not present & $56(39.4 \%)$ & 7 (41.2\%) & \multirow{2}{*}{$\begin{array}{l}\chi^{2}=0.02 \\
p=0.89\end{array}$} \\
\hline & present & $86(60.6 \%)$ & $10(58.8 \%)$ & \\
\hline
\end{tabular}

In the follow-up period, local recurrence of the disease occurred in 8 (4.9\%) patients within 5 to 120 months after the surgical treatment (Table III).

Distant metastases occurred in 13 (8.2\%) patients within 6 to 110 months after the surgical treatment, and in 1 patient 8 years before the operation of the primary focus in the lung. The primary location of remote carcinoid metastases was the liver (in 3 patients - with carcinoid syndrome). The remaining locations included, in order of frequency: the spine and skeleton, the other lung, skin, breast, thyroid gland, ovary, pancreas, kidney, and adrenal glands.

The treatment of distant metastases included metastasectomy (3 patients), chemotherapy, targeted radiation therapy using octreotide labeled with yttrium (90Y-DOTATATE) (3 patients), and treatment with Sandostatin LAR, a somatostatin analog (5 patients).

Among the 159 patients who underwent surgical treatment, 26 (16.4\%) died during the follow-up period, 2 of whom died because of other malignant neoplasms.

Tab. II. Histological subtypes of bronchopulmonary carcinoid tumor and pathological factors (tumor location, size, and stage according to TNM 1997)

\begin{tabular}{|c|c|c|c|c|}
\hline \multicolumn{2}{|c|}{ Pathological factors } & $\begin{array}{l}\text { Typical } \\
\text { carcinoid }\end{array}$ & $\begin{array}{l}\text { Atypical } \\
\text { carcinoid }\end{array}$ & $\begin{array}{c}\text { Statistical } \\
\text { analysis }\end{array}$ \\
\hline \multirow{2}{*}{ location } & central & 79 (55.6\%) & $8(47.1 \%)$ & \multirow{2}{*}{$\begin{array}{l}\chi^{2}=0.45 \\
p=0.50\end{array}$} \\
\hline & peripheral & $63(44.4 \%)$ & $9(52.9 \%)$ & \\
\hline \multirow{2}{*}{ tumor size } & average & $2.03 \mathrm{~cm}$ & $1.88 \mathrm{~cm}$ & \multirow{2}{*}{$p=0.94$} \\
\hline & range & $0.6-10 \mathrm{~cm}$ & $0.7-4 \mathrm{~cm}$ & \\
\hline \multirow{2}{*}{ T parameter } & $\mathrm{T} 1$ & $110(77.5 \%)$ & $11(64.7 \%)$ & \multirow{2}{*}{$\begin{array}{l}\chi^{2}=1.26 \\
p=0.26\end{array}$} \\
\hline & $\mathrm{T} 2, \mathrm{~T} 3$ & $32(22.5 \%)$ & $6(35.3 \%)$ & \\
\hline \multirow{2}{*}{ N parameter } & NO & 136 (95.8\%) & $14(82.3 \%)$ & \multirow{2}{*}{$\begin{array}{l}\chi^{2}=8.34 \\
p=0.015\end{array}$} \\
\hline & N1, N2 & $6(4.2 \%)$ & $3(17.7 \%)$ & \\
\hline \multirow{2}{*}{$\begin{array}{l}\text { progression } \\
\text { stage } \\
\text { (TNM 1997) }\end{array}$} & I & 105 (73.9\%) & 9 (52.9\%) & \multirow{2}{*}{$\begin{array}{l}\chi^{2}=3.30 \\
p=0.07\end{array}$} \\
\hline & II, III, IV & 37 (26.1\%) & $8(47.1 \%)$ & \\
\hline
\end{tabular}

Tab. III. Local recurrence in patients after surgical treatment due to bronchopulmonary carcinoid and the employed therapy

\begin{tabular}{|c|c|c|c|c|c|}
\hline $\begin{array}{l}\text { Age/sex } \\
(\mathrm{M} / \mathrm{W})\end{array}$ & $\begin{array}{l}\text { Carcinoid subtype/ } \\
\text { TNM } 1997\end{array}$ & Surgical treatment & $\begin{array}{l}\text { Time of } \\
\text { recurrence }\end{array}$ & Treatment used & Notes \\
\hline 50 years/W & typical T1NOMORO & lobectomy & 29 months & no consent for surgery & $\begin{array}{l}\text { unconventional } \\
\text { therapy/dead }\end{array}$ \\
\hline 32 years/W & typical T2NOMORO & lobectomy & 84 months & $\begin{array}{c}\text { complementary pneumonec- } \\
\text { tomy }\end{array}$ & alive \\
\hline 19 years/W & typical T2NOMORO & $\begin{array}{l}\text { bronchotomy with wedge resection } \\
\text { of the bronchus with the tumor }\end{array}$ & 5 months & complementary lobectomy & alive \\
\hline 68 years/W & atypical T1NOMOR0 & $\begin{array}{l}\text { Wedge resection +chemotherapy/ } \\
\text { radiotherapy }\end{array}$ & 30 months & $\begin{array}{l}\text { additional thoracotomy - ino- } \\
\text { perable lesion }\end{array}$ & dead \\
\hline 19 years/M & typical T2NOMOR1 & bilobectomy & 105 months & $\begin{array}{l}\text { inoperable recurrence; meta- } \\
\text { stasis to the pancreas and liver }\end{array}$ & $\begin{array}{l}\text { CHTH + sando- } \\
\text { statin/alive }\end{array}$ \\
\hline 43 years/M & typical T1NOMORO & wedge resection & 69 months & complementary lobectomy & alive \\
\hline 18 years / M & typical T1NOMORO & $\begin{array}{l}\text { bronchotomy with wedge resection } \\
\text { of the bronchus with the tumor }\end{array}$ & 108 months & lower and middle bilobectomy & alive \\
\hline 57 years/W & atypical T2NOMORO & lobectomy & 120 months & inoperable recurrence & $\begin{array}{c}\text { sandostatin/ } \\
\text { dead }\end{array}$ \\
\hline
\end{tabular}


The comparison of the long-term results of surgical treatment revealed significant statistical differences between the two bronchopulmonary carcinoid subtypes (Table IV).

In the analyzed group of 159 patients operated on for bronchopulmonary carcinoids, the median disease-free interval (DFI) was 92 months (range from 2 to 262 months). Statistical significance was found ( $p=0.00003$ ) when comparing the median DFI in patients with typical carcinoids (109 months) to the median DFI in the case of atypical carcinoids (35 months).

Tab. IV. Histological subtype of the bronchopulmonary carcinoid and the late results of surgical treatment in the study group

\begin{tabular}{lccc} 
Late results & $\begin{array}{c}\text { Typical } \\
\text { carcinoid }\end{array}$ & $\begin{array}{c}\text { Atypical } \\
\text { carcinoid }\end{array}$ & $\begin{array}{c}\text { Statistical } \\
\text { analysis }\end{array}$ \\
\hline local recurrence & $6(4.2 \%)$ & $2(11.8 \%)$ & $\begin{array}{c}\chi^{2}=1.40 \\
p=0.24\end{array}$ \\
\hline distant metastasis & $9(6.3 \%)$ & $4(23.5 \%)$ & $\begin{array}{l}\chi^{2}=4.39 \\
p=0.036\end{array}$ \\
\hline death & $18(12.7 \%)$ & $8(47.1 \%)$ & $\begin{array}{l}\chi^{2}=13.12 \\
p=0.0003\end{array}$ \\
\hline
\end{tabular}

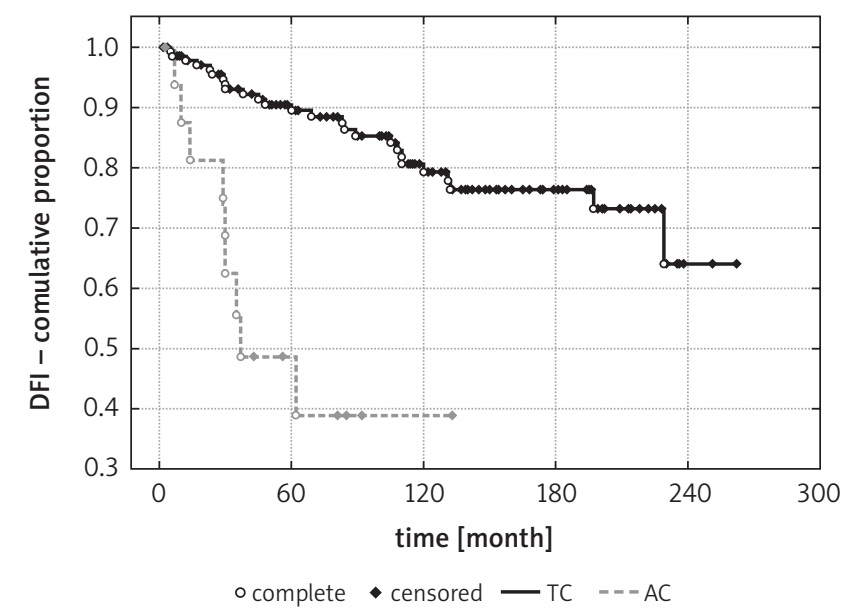

Fig. 1. Disease-free interval (DFI), depending on the histological subtype of bronchopulmonary carcinoid (TC - typical; AC - atypical)

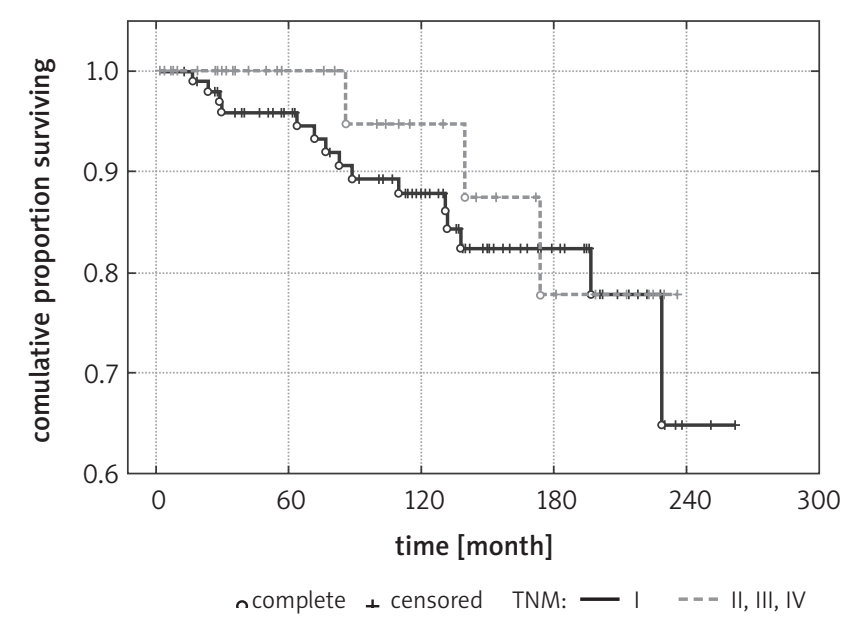

Fig. 3. Overall survival of patients with typical carcinoid (TC) depending on the severity according to TNM 1997 (I / II, III, IV)
Figure 1 shows the Kaplan-Meier curves used for estimating the DFI in dependence on the histological subtype of bronchopulmonary carcinoid, with significantly higher probability ( $p=0.00001$ ) of longer DFI for the group of patients with typical carcinoid tumors.

In the analyzed group of 159 patients operated on for bronchopulmonary carcinoids, the estimated probability was $91.9 \%$ for 5 -year survival and $78.5 \%$ for 10 -year survival.

Figure 2 shows the Kaplan-Meier curves used for estimating the overall survival in dependence on the histological subtype of carcinoid tumors. Statistically significantly ( $p<0.00001)$ higher probability of longer survival was confirmed for the group of patients with typical carcinoids.

Figure 3 shows the survival curves of patients with typical carcinoids in dependence on the degree of progression. A higher percentage of 5- and 10-year survival was noted in stage I patients than in stage II-IV patients. However, the difference was not statistically significant $(p=0.35)$.

Figure 4 shows the survival curves of patients with atypical carcinoids in dependence on the degree of pro-

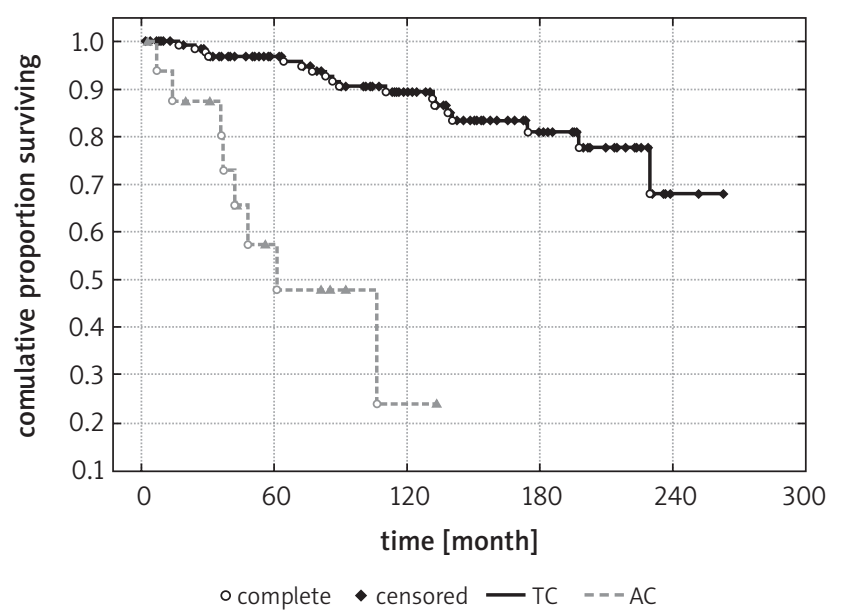

Fig. 2. Overall survival of patients according to the histological subtype of bronchopulmonary carcinoid (TC - typical; AC - atypical)

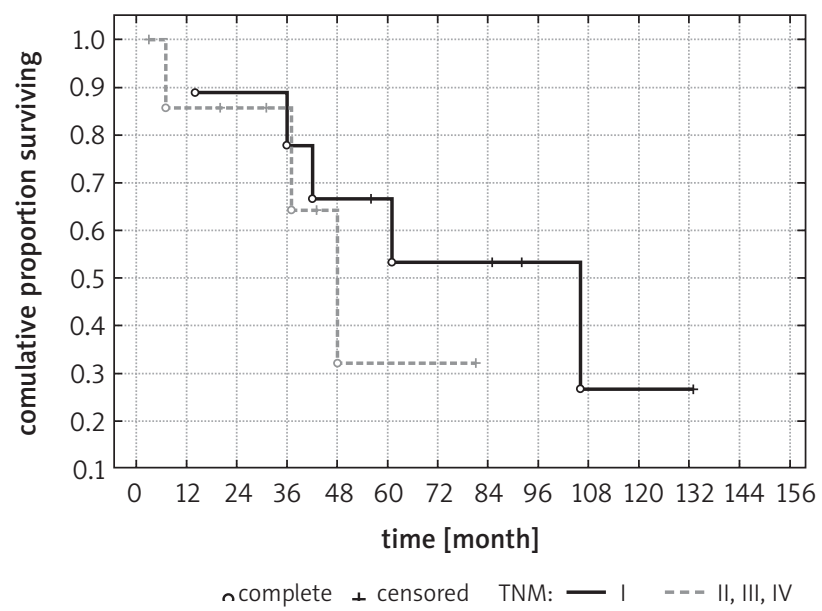

Fig. 4. Overall survival of patients with atypical carcinoid (AC), depending on the stage according to TNM 1997 (I, II, III, IV) 
gression. A higher percentage of 5-year survival was noted in stage I patients in comparison to other patients, but without statistical significance $(p=0.62)$.

\section{Discussion}

The most common manifestation age of bronchopulmonary carcinoids is $31-55$ years [2]. Some studies point to a slightly higher incidence in women [1]. In about $8 \%$ of cases, bronchopulmonary carcinoids occur before the age of 20. These are mainly childhood primary tumors, in some cases related to disturbances of embryogenesis. The average age in the discussed material was 52.6, with women constituting the majority of patients (64.2\%). Young people up to the age of 20 constituted $2.5 \%$.

The growth of carcinoids is locally infiltrative, but relatively slow ("cancer in slow motion"). It is estimated that a typical carcinoid tumor doubles its mass within 45 to 120 months (80 on average) [10]. In the discussed material, the course of the disease was asymptomatic in $39.6 \%$ of patients. In the remaining patients, symptoms appeared within the period between 2 weeks and 6 years. One male patient was diagnosed with Cushing's syndrome caused by ectopic ACTH secretion. The symptoms of carcinoid syndrome were observed before surgery in only one female patient $(0.6 \%)$. This is mainly due to the inactivation of vasoactive substances by high monoamine oxidase levels in pulmonary microcirculation, as well as the fact that bronchopulmonary carcinoids are often accompanied by a deficiency of 5-hydroxytryptophan (5-HTP) decarboxylase converting 5-HTP to serotonin (5-HT), which is metabolized to 5-HIAA identified in urine [2, 3].

The average time period between the detection of radiological changes in the lung and the operation varies in other studies, usually ranging from 14 to 37 months [11, 12]. In the analyzed group of patients this time interval lasted from 2 months to 10 years. This can be attributed to prolonged observations of "coin lesions" or erroneous initial diagnoses of lung diseases. In the literature a case of carcinoid diagnosed after 21 years of recurring lung infections is described [10]. Sometimes the distant metastases of lung carcinoids are diagnosed at the same time as the primary tumors [13], at times even preceding them [14], as in the case of one patient in the described material. It may happen that persistent cough and dyspnea, caused by the growing tumor and the slow occlusion of the bronchus, are diagnosed as asthma or COPD [15]. Patients are treated for these diseases for years before bronchoscopy provides the correct diagnosis.

Bronchopulmonary carcinoids may coexist with other neoplasms of the lung or other organs. Instances of mixed lung tumors have been described, for example carcinoid with adenocarcinoma. In other cases, these neoplasms occurred consecutively within several years. In the presented material, adenocarcinoma occurred in the other lung in one female patient 38 months after lobectomy performed because of typical carcinoid tumor.

Within recent years, it has been emphasized that MEN-1 should be taken into consideration in the case of pathologies that may potentially constitute one of its parts [16].
In young women, the presence of neuroendocrine tumors of the thymus and bronchopulmonary carcinoids should be a signal to perform genetic examination for MEN-1.

Coexisting endocrine (bronchopulmonary, thymic and gastric carcinoids, tumors of adrenal and thyroid glands) and non-endocrine diseases (myoma, lipoma, CNS tumors and various skin lesions) are being diagnosed with increasing frequency $[16,17]$. In the analyzed material, bronchopulmonary carcinoid tumors occurred in 18 patients with diseases of the thyroid gland (non-toxic nodular goiter, Hashimoto's struma, hyper- and hypothyroidism, follicular carcinoma), in 3 patients with CNS tumors (meningioma of the brain and glioma of the cerebellum) and in one female patient with hyperparathyroidism and pituitary prolactinoma treated conservatively with quinagolide (Norprolac - Novartis Pharma AG). In the latter case, MEN-1 syndrome was diagnosed and genetically confirmed. According to American epidemiological research, the presence of bronchopulmonary carcinoid increases the risk of hormonally dependent neoplasms, including breast and prostate cancer, within a given population [18]. This can be explained by the role of genetic and hormonal factors, which are important in relation to bronchopulmonary carcinoid and are still subject to research.

Preoperative confirmation of carcinoid was achieved in $87.5 \%$ of patients with central tumors (in comparison to $14-85 \%$ of diagnoses found in other authors) and in 5 cases with peripheral tumors on the basis of fine needle biopsy (which occurs very rarely). The neoplasm was incorrectly diagnosed in 7 (4.4\%) patients in total, which is comparable to the figures presented by other authors.

The therapy of choice for bronchopulmonary carcinoids is surgical treatment compliant with oncological surgery guidelines, with maximum sparing of the healthy lung tissue. Pulmonary parenchyma requires thorough palpatory intraoperative examination due to the possibility of the coexistence of numerous carcinoids, concomitant DIPNECH foci (constituting a precancerous condition), as well as the presence of neuroendocrine tumorlet type nodules, which are precursors to peripheral bronchopulmonary carcinoids.

In $11(6.9 \%)$ selected cases of small polypoid tumors on long thin stems, which were entirely intrabronchial, bronchotomy was performed with wedge resection of the bronchus with the tumor. Currently, sleeve resection of the fragment of the bronchus containing the tumor is more frequently performed. This is essential, particularly in the case of sessile tumors located centrally, which have a slightly worse prognosis than polypoid carcinoids on long stems [19]. If the tumor is centrally located, pneumonectomy should be avoided in favor of bronchoplastic surgery. Local recurrence occurred in 2 bronchotomy cases: after 5 and 108 months, respectively. Sleeve resection of the bronchus was performed in 3 patients (1.9\%).

The most frequently performed surgery was lobectomy and bilobectomy (103 cases, $64.8 \%$ ); this percentage is slightly lower in comparison to data in the literature (65-72\%). In the study material, pneumonectomy was performed in $4(2.5 \%)$ patients, which is in accordance with other publications [20, 21]. 
In regard to carcinoids, the procedures of wedge resection and segmentectomy are reserved for patients with low breathing reserve, as confirmed by spirometry. In the study material, segmentectomy and wedge resection were performed in 38 (23.9\%) patients in total: a number which is slightly higher than in the reports of other authors [21, 22]. A considerable percentage of patients, both in the case of typical (73.9\%) and atypical carcinoids (52.9\%), were operated on while in stage I (according to TNM 1997), which is in concert with other publications.

The analyzed material included one patient who was operated on despite the fact that atypical carcinoid metastasis to the liver had been confirmed 8 years earlier. Similar examples of surgical treatment of stage IV carcinoid tumors have been described by other authors. Surgery should not be discarded even if metastasis is present, because reducing tumor mass produces clinical improvement.

A bronchopulmonary carcinoid tumor may recur locally at different postoperative times, sometimes as late as 30 years after the surgery $[12,20]$. In the discussed material, local recurrence occurred in 8 patients within the period between 5 and 120 months. At a later time, even after a dozen or more years, the tumor may also be a source of distant metastases to the liver, bones, skin, breasts, adrenal glands, uterus, kidneys, pancreas, spleen, peritoneal cavity, or even the eyeballs.

A breakthrough in the symptomatic treatment of neuroendocrine tumors was achieved by employing somatostatin analogs which bind directly to their receptors (SSR 1-5 subtypes), inhibiting the pathologically increased hormone secretion and exerting an antiproliferative effect, thus inhibiting growth factors and angiogenesis, while inducing apoptosis. In the discussed material, 4 progressing patients with metastasis and symptoms of carcinoid syndrome received a long-acting preparation of octreotide - Sandostatin LAR (Novartis).

After demonstrating receptor expression for somatostatin in receptor scintigraphy (SRS) by means of octreotide labeled with indium or technetium, one can consider employing targeted radioisotope therapy with labeled somatostatin analogs, which specifically bind to neoplastic cells via the receptor, while the ionizing radiation of the radioisotope destroys the lesions.

In the study material, targeted 90Y-DOTA-TATE radioisotope therapy was used in three patients with metastases to the liver. It is a promising therapy for progressing patients and patients with diffuse, inoperable neuroendocrine neoplasms; it is, however, burdened with an adverse side effect, i.e. kidney damage [23]. Receptor scintigraphy is currently the most sensitive tool for diagnosing local recurrence and metastasis of neuroendocrine tumors and can be of help in planning further treatment.

The study results in the discussed material concern patients who underwent surgery in the years 1990 to 2011. This is one of the reasons for the differences in the diagnosis of the 9 tumors, which were reclassified after histopathological verification in accordance with the 1999 WHO classification
(Travis). Tumor evaluation in accordance with the new criteria is characterized by stronger correlation with their later behavior and patient survival, which proves that detailed and precise identification of the neuroendocrine tumor type is essential for the prognosis and treatment planning.

In concert with the observations of other authors, the correlation between age, gender, and the malignancy grade of bronchopulmonary carcinoids was confirmed [4, 13, 24]. The average age of the patients with atypical carcinoid tumors was 4.2 years higher than that of the patients with typical carcinoids, while the incidence among men was $12.6 \%$ higher for atypical carcinoids than for typical carcinoids.

In the study group, stage II-IV patients were dominant in the atypical carcinoid subtype (47.1\%) in comparison to the typical carcinoid subtype $(26.1 \%)(p=0.07)$.

In accordance with other reports [4, 13, 24], the involvement of the N1 and N2 lymph nodes was more frequently noted in the atypical carcinoid group (17.7\%) than in the typical carcinoid group (4.23\%), with a statistically significant difference $(p=0.015)$. Several studies can be found in the literature which precisely analyze the results of lymph node involvement in patients with bronchopulmonary carcinoids, and the significance of this fact for the prognosis $[13,24,25]$. Most analyses have confirmed that lymph node involvement does not exert a significant influence on the prognosis in the case of typical carcinoids, but is of key importance in the case of atypical carcinoids [13, 26, 27].

The median DFI was longer by 74 months for the patients with typical carcinoids than for the patients operated on for atypical carcinoids $(p=0.00003)$. Local recurrence of atypical carcinoids was more frequent than that of typical carcinoids, but without the significant differences $(p=0.2)$ that were found in other studies [13], while the percentage of distant metastases was higher in the atypical subgroup than in the typical subgroup by $17.2 \%(p=0.036)$, in accordance with other publications [4, 24]. In these studies, the frequency of distant metastasis was 5-10\% for typical carcinoids and $60-70 \%$ for atypical carcinoids. In the presented material, these values are, respectively, $6.34 \%$ and $23.5 \%$.

The 5-year survival percentage in the study group demonstrated dependency on the stage of progression in the case of both typical carcinoids $(p=0.35)$ and atypical carcinoids $(p=0.62)$; however, the differences were not statistically significant.

The comparison of the number of deaths in the study group during follow-up (47.1\% for atypical carcinoids and $12.7 \%$ for typical carcinoids, $p=0.0003)$, as well as of survival rates of the two subgroups $(p<0.00001)$, is in concert with reports by other authors [13, 21, 24, 25, 27] and indicates much stronger biological aggressiveness of atypical carcinoids. These results indicate the need for detailed and precise differentiation between the histological subtypes of bronchopulmonary carcinoids.

\section{Conclusions}

1. The treatment of choice for bronchopulmonary carcinoids is surgical treatment compliant with oncological surgery 
guidelines, with maximum sparing of the healthy lung tissue, and complemented with systemic lymphadenectomy (particularly if dealing with atypical carcinoids).

2. The histological subtype of a bronchopulmonary carcinoid tumor, defined by appropriate parameters (mitotic activity, proliferative index Ki-67, the presence of necrosis and angioinvasion in the tumor), is the dominant prognostic factor for evaluating the DFI and 5-year survival rates after surgical treatment.

3. Bronchopulmonary carcinoid tumors are potentially malignant neoplasms which are sometimes misdiagnosed; they constitute potential sources of distant metastasis and late local recurrence after surgery and require longterm follow-up.

4. Defining uniform standard procedures for diagnosing, classifying, and treating neuroendocrine tumors of the respiratory system may regulate and facilitate the comparisons of homogeneous study groups and multicenter prospective studies.

\section{References}

1. Cooper WA, Thourani VH, Gal AA, Lee RB, Mansour KA, Miller JI. The surgical spectrum of pulmonary neuroendocrine neoplasms. Chest 2001; 119: 14-18.

2. Bertino EM, Confer PD, Colonna JE, Ross P, Otterson GA. Pulmonary neuroendocrine/carcinoid tumors: a review article. Cancer 2009; 115: 4434-4441.

3. Weissberg D. Nowotwory gruczołów oskrzelowych. Pol Przeg Chir 2000; 9: 871-880.

4. Travis WD. The concept of pulmonary neuroendocrine tumourus in pathology and genetics of tumours of the lungs, pleura, thymus and heart. In: Travis WD, Brambilla E, Muller-Hermelink HK, Harris CC. Pathology and Genetics of Tumours of the Lung, Pleura, Thymus and Heart. IARC Press, Lyon 2004; $19-62$.

5. Langfort R, Rudziński P, Burakowska B. Rozrosty neuroendokrynne płuc. Histologiczne spektrum podtypów, aktualne poglądy dotyczące rozpoznawania i leczenia. Pneumonol Alergol Pol 2010; 78: 33-46.

6. Papla B, Zieliński M, Kuzdzał J, Harazda M. Hyperplasia of endocrine cells, tumorlets and atypical carcinoid of the lung - a case report. Pol J Pathol 2004; 55: 31-33.

7. Greenberg AK, Yee H, Rom WN. Preneoplastic lesions of the lung. Respir Res 2002; 3: 20.

8. Kerr KM. Pulmonary preinvasive neoplasia. J Clin Pathol 2001; 54: 257-271.

9. Wysocka J, Wysocki W, Kruszyna T. Nowotwory neuroendokrynne przewodu pokarmowego. Nowa klasyfikacja TNM (2010 r.). Med Prakt Chir 2011; 4: 92-96.

10. Jędruszczak B, Decker E, Kamiński Z, Gątarek J, Burakowska B. Przypadek rakowiaka płuca rozpoznany po 21 latach nawracających zakażeń płuc. Pneumonol Alergol Pol 1995; 63: 64-71.

11. Smolle-Jüttner FM, Popper $\mathrm{H}$, Klemen $\mathrm{H}$, Pinter $\mathrm{H}$, Pongratz-Roeger $\mathrm{M}$, Smolle J, Friehs G. Clinical features and therapy of „typical” and „atypical” bronchial carcinoid tumors (grade 1 and grade 2 neuroendocrine carcinoma). Eur J Cardiothorac Surg 1993; 7: 121-124.
12. Vadasz P, Palffy G, Egervary M, Schaff Z. Diagnosis and treatment of bronchial carcinoid tumors: clinical and pathological review of 120 operated patients . Eur J Carciothorac Surg 1993; 7: 8-11.

13. García-Yuste M, Matilla JM, Cueto A, Paniagua JM, Ramos G, Cańizares MA, Muguruza I; Spanish Multi-centric Study of Neuroendocrine Tumours of the Lung for the Spanish Society of Pneumonology and Thoracic Surgery (EMETNE-SEPAR). Typical and atypical carcinoid tumours: analysis of the experience of the Spanish Multi-centric Study of Neuroendocrine Tumours of the Lung. Eur J Cardiothorac Surg 2007; 31: 192-197.

14. Pinchot SN, Holen K, Sippel RS, Chen H. Carcinoid tumors. Oncologist 2008 ; 13: $1255-1269$

15. Piotrowski WJ, Zięba M. Bronchial carcinoid presenting as asthma. Curr Pneumol 1997; 1: 109-112.

16. Krassowski J. trudności w rozpoznawaniu i leczeniu MEN1. Endokr Pol 2005; 56: 303-307.

17. Asgharian B, Turner ML, Gibril F, Entsuah LK, Serrano J, Jensen RT. Cutaneous tumors in patients with multiple endocrine neoplasm type 1 (MEN1) and gastrinomas: prospective study of frequency and development of criteria with high sensitivity and specificity for MEN1. J Clin Endocrinol Metab 2004; 89: 5328-5336.

18. Cote ML, Wenzlaff AS, Philip PA, Schwartz AG. Secondary cancers after a lung carcinoid primary: a population-based analysis. Lung Cancer 2006; 52: 273-279.

19. Kurul IC, Topçu S, Taştepe I, Yazici U, Altinok T, Cetin G. Surgery in bronchial carcinoids: experience with 83 patients. Eur J Carciothorac Surg 2002; 21: 883-887.

20. El Jamal M, Nicholson AG, Goldstraw P. The feasibility of conservative resection for carcinoid tumours: is pneumonectomy ever necessary for uncomplicated cases? Eur J Cardiothorac Surg 2000; 18: 301-306.

21. Ferguson MK, Landreneau RJ, Hazelrigg SR, Altorki NK, Naunheim KS, Zwischenberger JB, Kent M, Yim AP. Long-term outcome after resection for bronchial carcinoid tumors. Eur J Cardiothorac Surg 2000; 18: 156-161.

22. Ullmann R, Petzmann S, Klemen H, Fraire AE, Hasleton P, Popper HH. The position of pulmonary carcinoids within the spectrum of neuroendocrine tumors of the lung and other tissues. Genes Chromosomes Cancer 2002; 34: 78-85.

23. Kunikowska J, Królicki L, Ćwikła J, Mikołajczak R, Pawlak D, Korsak A, Kozłowicz I, Poprawski J, Płazińska M, Kobylecka M, Mączewska J, Życińska K, Wardyn K. Przebieg leczenia nowotworów typu NET pochodnymi somatostatyny znakowanymi radioizotopowo. Endokr Pol 2005; 56: 37-64.

24. Rea F, Rizzardi G, Zuin A, Marulli G, Nicotra S, Bulf R, Schiavon M, Sartori F. Outcome and surgical strategy in bronchial carcinoid tumors: single institution experience with 252 patients. Eur J Cardiothorac Surg 2007; 31: 186-191.

25. Cardillo G, Sera F, Di Martino M, Graziano P, Giunti R, Carbone L, Facciolo F, Martelli M. Bronchial carcinoid tumors: nodal status and long-term survival after resection. Ann Thorac Surg 2004; 77: 1781-1785.

26. Mezzetti M, Raveglia F, Panigalli J, Giuliani L, Lo Giudice F, Meda S, Conforti $\mathrm{S}$. Assessment of outcomes in typical and atypical carcinoids according to latest WHO classification. Ann Thorac Surg 2003; 76: 1838-1842.

27. Cao C, Yan TD, Kennedy C, Hendel N, Bannon PG, McCaughan BC. Bronchopulmonary carcinoid tumors: long-term outcomes after resection. Ann Thorac Surg 2011; 91: 339-343. 